\title{
Research on the Selection and Application of Sports Policy Tools in China's Colleges and Universities
}

\author{
Shengmin Cao \\ Physical Education Department \\ Laboratory of Education Economy and Management \\ School of Humanities and Law \\ Northeastern University \\ Shenyang, China 110819
}

\author{
Wanbing Shi \\ Department of Education Economy and Management \\ School of Humanities and Law \\ Northeastern University \\ Shenyang, China 110819
}

\begin{abstract}
Exploring and analyzing the selection and application of sports policy has great importance and value on the implantation of sports policy in China's colleges and universities. According to the core concept of policy tool, sports policy and its aim, we can get a clear picture of the selection and application of sports policy in colleges and universities through demonstrating and analyzing authority, ability, study and symbol and persuasion tools. Meanwhile, we can also find the methods and ways for achieving the goal of improving sports policy in colleges and universities and put forward practical advice for optimizing sports policy to advocate physical education in colleges and universities and improve the health of young generation.
\end{abstract}

Keywords-sports policy in colleges and universities; policy tool; authoritative tool; competency tool; incentive tool; symbol and persuasion tool; learning tool

\section{INTRODUCTION}

In order to do a good job in sports education in colleges and universities, the CPC Central Committee Political Bureau, the State Council, the Ministry of Education and relevant departments have issued a series of laws, regulations and meeting summaries for improving higher education. While in fact, the promotion of sports higher education in colleges and universities to improve physical health of young generations hasn't been fully realized. Based on this point, the author has taken the sports policy launched by colleges and universities as the accordance, and analyzed public policies to help find the methods and ways of realizing the objectives of higher sports education and promoting its smooth development. ${ }^{[1]}$

\section{DEFINITION OF CORE CONCEPT}

\section{A. Policy Tool}

Policy tool, also known as government tool or governance tool, has been given different definitions by different scholars. Ingram and Schneider have pointed out that policy tool serves as a purposeful blueprint for action. In other words, policy tool is developed to solve problems and achieve goals, and it is also a set of plans that can help achieve policy objectives. Hood argues that policy tool is the process by which governments use a set of administrative tools to achieve goals in many different scenarios through different kinds of tools. [2] Chen Zhenming believes that the specific way that people adopt to solve social problems or achieve goals in policy is policy tool. ${ }^{[3]}$

All in all, policy tool is a method or way that political parties, governments, or other social groups use to address specific social problems or achieve certain policy objectives.

\section{B. Sports Policy in Colleges and Universities}

The term "policy" is a borrowed word from Japan at the end of the 19th century. During Meiji Restoration, "Policy" was introduced from western countries. And as its meaning was similar to the Chinese characters "politics" and "policy", it was translated into policy. ${ }^{[4]}$ As Easton puts it "public policy is to distribute the value of the society." [5] Laswell, the main founder and advocate of policy science, regards policy as "a plan of large scale with goals, values and strategies." [6] Su Jun defines public policy as the code of conduct or political action taken by governments, political parties and other social organizations in certain periods to achieve specific political, economic, cultural and social objectives. It is a generic term of a series of regulations, methods, measures, decrees, laws, strategies and so on. ${ }^{[7]}$

Education policy is in the process of an organized dynamic development with purpose, and it is also an accordance and guideline of action for realizing educational objectives and coordinating tasks in certain historical period put forward by political party and government. ${ }^{[8]}$ There hasn't been clear definition of sports policy in colleges and universities by scholars so far. By summing up the views of scholars, the author believes that sports policy in colleges and university is the action accordance and guideline provided by political parties, government and other social organizations in a specific historical period to achieve higher education sports education objectives and it is a generic term of series of regulations, notices, methods, measures, decrees, laws, strategies. 


\section{Objectives for Sports Policy in Colleges and Universities}

Objective is to achieve the desired results through great efforts. The objective of education is the result of educational activities, and it is the starting point and destination of education. In 2012, the 18th National Congress of the Communist Party of China (CPC) reported that education was an important aspect of improving people's livelihood and social construction, the core of which was stated clearly that "do well in education to meet people's satisfaction". China's education policy objectives that "do well in education to meet people's satisfaction" has gradually become the mainstream of the education. In fact, the evaluation standard of China's education policy is becoming education satisfaction. ${ }^{[9]}$

In general, the author holds the opinion that the goal of higher education policy in colleges and universities is to achieve the goal of higher education sports objectives under the guidance of the educational policy of moral, intellectual and physical development. It is the origin and objective for higher education sports policy and the standard for political party, government, administrative education departments and relevant departments to evaluate higher education sports policy.

\section{THE SELECTION AND APPLICATION OF POLICY TOOLS FOR THE REALIZATION OF HIGHER EDUCATION POLICY OBJECTIVES}

The function of policy tool in achieving the policy objectives of higher education sports policy in China and the effect in the practice of sports system in colleges and universities will directly affect the physical health of students and the management efficiency of higher education in our country. There are many kinds of policy tools. Based on Ingram \& Schneider's classification of policy tools, this paper has analyzed the sports policy in colleges and universities. Based on their behavioral assumption of theoretical basis, Ingram and Schneider identified five policy tools: authoritative tool, incentive tool, competency tool, learning tool, and symbol tool and persuasion tool. ${ }^{[10]}$

\section{A. Authoritative Tool}

The authoritative tool is the most concise and effective way for government in the formulation and implementation of sports policy in colleges and universities. It is embodied in law, regulation, permission, order, plan, punishment and control. In 1951, the Central People's Government Administration Committee issued Decision to Improve the Health Status of Students in School at all Levels, aimed at improving the health of students, improving students' physical health, regulating the daily learning and spare time of students, sports and recreational activities, food, healthcare and other aspects. With the development and progress of society, the reform of college and university sports has been refined and deepened, and the laws and regulations on sports in colleges and universities have been gradually improved. The Law of the People's Republic of China on Teachers' Law, the Higher Education Law of the People's Republic of China, the Education Law of the People's Republic of China, and the Sports Law of the
People's Republic of China clearly stipulate the responsibilities, rights and obligations of the relevant subjects of colleges and universities, sports departments, teachers and students. It has provided a legal guarantee for institutions of higher education in the training of qualified personnel for national construction.

With sound laws and regulations, we have made the regulations, standards, programs, laws and other specific measures operational and promote healthy development of students. Regulations of School Sports Education, Physical Education Curriculum Guiding Outline for Common Institutes of Higher Learning in China, Fitness and Health Standard of Students, National Student Sports Competition Management Regulations and other documents stress that higher education sports education should be administrated by education department, under the guidance of education policy by CPC to cultivate national builders and their successors and put people's health in the first place. Comprehensively evaluating the overall quality of college students, measuring the development of sports in colleges and universities, assessing higher education in colleges and universities, testing the level of teaching and extracurricular training, and promoting the development of sports education in colleges and universities.

\section{B. Incentive Tool}

The use of incentive tool and its obedience is realized by practical returns. To make the individuals carry out the policy requirements actively, the organization or individuals need to be given such returns as freedom, life, material, money and other things. The incentive tool is one of the characteristics of sports policy in colleges and universities, which is an important tool in the process of implementing government policies. The subjects of the policies can make use of the actual interests, costs and probabilities by it.

Teaching evaluation has incentive function, which is neither directly to the financial affairs nor the allocation of resources. Its main driving force is the recognition of the original status instead of enlarging the gap. Although the evaluation of teaching is not perfect, it can draw attention, because the evaluation results are easy to be accepted by the students. In this way, the reputation of colleges and universities, their enrollment and student employment can be impacted deeply, the effect of incentive tool amplified at the same time. In order to improve sports education in colleges and universities, the evaluation should not only be on teaching, but also on its system.

Reward and recognition are also the embodiment of incentive tool. "The Educational Law of the People's Republic of China" stipulates that teachers and educators who do the long-term teaching and researching service management work with significant results should be awarded the "National Excellent Teachers" and "National Outstanding Educators" honorary title, issued the appropriate Medals and certificates; to those who make outstanding contributions should be awarded the "National Model Teacher" and "National Education System Excellent Teacher" honorary title by the Ministry of Education and the 
Ministry of Human Resources and Social Security. These commendations and rewards can motivate individuals and organizations to generate an inherent motivation to help achieve the goals of sports policy in colleges and universities.

\section{Competency Tool}

The competency tool is that the target group are willing to change their behavior to participate in the activities in order to achieve the policy objectives if the resources needed are given to them. Basic security is an important part of the competency tool, and it is also the mean resource to maintain the living of individuals and the organizations. In a society with risks almost everywhere, it provides the minimum protection for individuals or organizations in the competitive environment. Funding is the main form of basic security. Higher educational sports funding mainly includes sports business fees, equipment costs, teachers' clothing costs, school team training fees, sports venues equipment costs, venues center operating costs, maintenance fees and other fees. The normal running of sports education in colleges and universities depends on these costs to guarantee the realization of policy objectives.

One can't make bricks without straw. It is an important part of the competency tool to be a resource guarantee for the goal of carrying out the sports policy of higher education. General Institute of Higher Education Sports Venues Facilities, Equipment Catalogue is a competency tool based on the condition of China's current sports facilities in colleges and universities for the overall development of higher education. It is also the specific requirement to acquire essential material for achieving the objectives of sports policy, and the important content for measuring higher education, the implementation of health first guiding ideology.

\section{Learning Tool}

Learning tool is an important tool for improving learners' learning ability and promoting policy implementation, who can gain experience through hearings, formal assessments, and the interaction with target groups and institutions, provide judgment for fundamental organizations, and participate in tool selection policy. Learning tool uses "bottom-up" behavior and is consistent with the policy environment. Higher education is facing different groups of students with different needs, teachers with different capacity structures, and the increasing number of employers. These target groups have the similarity of changing and highly diversifying with the situation. Therefore, if we want to improve the judgment of colleges and universities, the shackles of higher education should be lifted. In 2015, the General Office of the Ministry of Education promulgated the Notice of the General Office of the Ministry of Education on the Seminar of Educational Art in 2015. Through discussion on sports art of colleges and universities, sports art education theory and cultivation of the administrative departments and the leading cadres of higher education has been built, the leaders' decision- making ability improved, the innovation and development of sports education in colleges and universities promoted.

\section{E. Symbol and Persuasion Tool}

Symbol and persuasion tool means that when the policy requires target groups' behavior to be the consistent with values, they will be more willing to do it. Through intangible values, people's understanding of policy objectives and actions will be changed, without decreasing their tangible benefits. The concept of "health first", "lifelong sports" and "happy sports", which affect the sports policy of higher education in our country, plays an important role in the development and reform of higher education in China in the corresponding historical period. In 2006, the Ministry of Education, the State Sports General Administration, propagated the spirit of "Green Olympics, Science and Technology Olympics, Humanistic Olympics" and "Health First" guiding ideology. Olympic knowledges and culture were spread to students in colleges and universities. It pointed out that Olympic was the stage for young generations to show their talents and energy. In 2006, The Decision on the Implementation of the National Hundreds of Millions of Students for Sun Sports by the Ministry of Education, the State Sports General Administration and the Central Committee of the Communist Youth League pointed out that good atmosphere of public opinion should be built, so that "Exercise one hour a day, health for working 50 years, happiness for whole life " could be well-known. Under the guidance of CPC's education policy, the guiding ideology of "health first" should be implemented, and the combination of classroom teaching and extracurricular exercise, after-school training and sports competition should be carried out, the interaction between sports culture activities and those outside school should also be advocated. In this way, the overall improvement of student health and mass sports training boom can be realized.

\section{RECOMMENDATIONS FOR THE OPTIMIZATION OF CHINA'S SPORTS POLICY}

\section{A. Continue to Strengthen the Authoritative Tool}

The authoritative tool can help reflect the government's proposition and highlight its will. It is not flexible in the settlement of conflicts and rigid to solve some specific problems, but it can express government intentions simply and effectively. There are many requirements for the rights and responsibilities of target groups in the existing sports policy of higher education, and the standard of obligation is also clear. However, there is no disciplinary action for the violation of the obligation performance, which leads some colleges and universities not to perform or perform ineffectively an activity although they know that they are obliged to do so. China's higher education sports policy in the punishment of the provisions should be clearly rectified to enhance its deterrence, so that colleges and universities can not violate the policy and ensure the effectiveness of its implementation. 


\section{B. Implementation of Incentive Tool and Competency Tool}

Incentive tool and competency tool are the material and spiritual encouragement of policies that reallocate social values. The material incentive of sports policy in colleges and universities requires colleges and universities to implement it according to their own conditions. They can have good performance in sports venues infrastructure, and teachers, so that those who have no condition for it cannot experience such things. Besides, honorary title can be given to them for spiritual encouragement. In order to better perform the function of incentive tool and competency tool, the government department should implement the material incentive dominated on government fees, and combine honorary title with performance. In this way, spiritual encouragement can be realized by material.

\section{Prioritize the Introduction of Symbol Tool, Persuasion Tool, and Learning Tool}

There is special historical background for the policymaking and its implementation. And all the target groups have their own values. These three tools can encourage people from internal part to form long-term effective mechanism. Policy continuity, stability and cyclicality can also be guaranteed, so that long-term benefits and short-term goals can combine to avoid the low effectiveness due to passage of time and thus affect the realization of policy objectives.

\section{CONCLUSION}

To sum up, the selection and application of policy tools is a complex activity. Every policy has its own function and environment for its performance. The selection and application of policy tools requires the government to adjust according to its environment. The authoritative tool is the preference of our government to achieve the goal of sports policy in colleges and universities. Special conditions are needed for competency tool to perform its function. Ability to work effectively requires certain conditions. The use of incentive tool, symbol and persuasion tool is becoming the leading policies for the future sports development in colleges and universities. Learning tool in some cases can promote the self-innovation of the sports sector in colleges and universities. In order to promote the reform and development of higher education in colleges and universities and to achieve the goal of higher school sports policy, the government should choose the corresponding policy flexibly for promoting the implementation of sports policy effectively in colleges and universities.

\section{REFERENCES}

[1] Zhang Wengpeng, Wang Jian. Sports Policy Evolution since the Founding of PRC: Based on the Study on Policy Text [J]. Sports Science, 2015, (2): 14-23.

[2] Li Yunjie, Qiu Changtai. Policy Implementation and Evaluation [M]. Beijing: Peking University Press, 2008: 102-103.

[3] Chen Zhenming. Policy Science - Introduction to Public Policy Analysis [M]. Beijing: Chinese Renmin University Press, 2003: 170.
[4] Lan Bingjie, Diao Tianding. Policy Science [M]. Beijing: Social Science Literature Publishing House, 2009: 91-93.

[5] Easton D. The Political System.New York: Kropf, 1953: 129.

[6] Lasswell H D, Kaplan A.Power and Society. New Haven: Yale University Press, 1970: 71.

[7] Su Jun. Public Science and Technology Policy Introduction [M] Beijing: Science Press, 2014: 9.

[8] Shi Wanbing. Education Administration [M]. Beijing: Education Science Press, 2005: 227.

[9] Chen Shuangye, Meng Liujin. Public Opinion in the Education Policy Objectives, Issues Concerned and Value of Expression: Two Top Ten News List of the Discourse Analysis [J] Peking University Education Review, 2014 (4): 117

[10] Anne L. Schneider, Helen Ingram (1990) .Behavioral assumptions of policy tool. Journal of Politics, 52 (2): 514-521. 